\section{Tree Form and Heading Height at Planting Affect Peach Tree Yield and Crop Value}

\author{
Richard P. Marini ${ }^{1}$, Donald S. Sowers ${ }^{1}$, and Michele Choma Marini ${ }^{2}$ \\ Virginia Polytechnic Institute and State University, Blacksburg, \\ VA 24061-0327
}

Additional index words. Prunus persica, canopy volume, fruit weight

\begin{abstract}
Sweet Sue' peach (Prunus persica $\mathrm{L}$. Batsch) trees were subjected to a factorial arrangement of treatments. At planting, trees were headed at 10 or $70 \mathrm{~cm}$ above the bud union and trees were trained to an open-vase or central-leader form. For the first 4 years, high-headed trees were larger than low-headed trees. After 7 years, open-vase trees had larger trunk cross-sectional area, tree spread, and canopy volume than central-leader trees. Open-vase trees had higher yield and crop value per tree, but lower yield and crop value per unit of land area or unit of canopy volume than central-leader trees. Crop density and yield efficiency were similar for all treatments.
\end{abstract}

In the mid-Atlantic region of the United States, peach yields in mature orchards are often <21 t.ha ${ }^{-1}$. Apple (Malus domestica Borkh.) orchards, by contrast, often produce $>40$ t.ha ${ }^{-1}$. Because the harvest index, or the proportion of the total dry weight that is allocated to fruit, is $\approx 0.4$ for peach (Miller and Walsh, 1988) and apple (Forshey and McKee, 1970), the difference in yield is not due to differences in carbohydrate partitioning. Low peach yields likely are due to the low openvase training system used for peach. Peach trees are trained to the open-vase form by selecting three or four scaffold branches 45 to $60 \mathrm{~cm}$ above ground. Scaffold branches are oriented $\approx 60^{\circ}$ from horizontal and mature tree height is $\approx 2.5 \mathrm{~m}$ above ground. The interior portion of the tree contains few fruiting shoots (Marini, 1990). Keeping the tree center free of vegetation allows good light penetration throughout the canopy (Marini and Marini, 1983), but there is little fruiting wood per unit of land area (Miller and Walsh, 1988).

In peach orchard system trials, centralleader trees usually outyielded open-vase trees on a per hectare basis, but central-leader trees also were planted at closer spacings (DeJong, 1988; Menzies, 1988; Taylor, 1988), and high yields were associated with high tree densities. Apple yields increased with increasing light interception per unit land area (Jackson, 1978), as achieved with high-density plantings. Light distribution throughout the canopy was important for high fruit quality for peach (Marini et al., 1991), apple (Campbell and Marini, 1992), prune (Prunus domestica L.) (Southwick et al., 1990), and cherry (Prunus avium L.) (Patten and Proebsting, 1986). A conical tree form allowed good penetration of

Received for publication 15 Feb. 1995. Accepted for publication 7 June 1995 . The cost of publishing this paper was defrayed in part by the payment of page charges. Under postal regulations, this paper therefore must be hereby marked advertisement solely to indicate this fact.

${ }^{1}$ Dept. of Horticulture.

${ }^{2}$ Dept. of Statistics. light throughout the canopy (Jackson, 1980). The conical tree form, commonly used for apple, may be conducive to higher yields of quality peaches per hectare due to increased fruiting wood per unit area. Our study was conducted to compare productivity and crop value of open-vase and central-leader peach trees planted at the same spacing and headed at two heights at planting.

\section{Materials and Methods}

Plant material. Forty 'Sweet Sue' trees on Lovell rootstock were planted at a $5 \times 6.5-\mathrm{m}$ spacing on 8 Apr. 1986 at the Virginia Tech Horticultural Research Farm near Blacksburg. Trunk diameter at planting was $>2.2 \mathrm{~cm}$ and trees were planted with the bud union $5 \mathrm{~cm}$ above the soil surface. The following four treatments were assigned randomly to each of 10 trees: 1) low-heading open-vase training; 2) high-heading open-vase training; 3) lowheading central-leader training; 4) high-heading central-leader training. On 16 Apr. 1986, trees designated as low heading were headed at $10 \mathrm{~cm}$ above the bud union, and trees designated as high heading were headed at 70 or 90 $\mathrm{cm}$ above the bud union for open-vase and central-leader trees, respectively. Trees were trained to an open-vase or central-leader form.
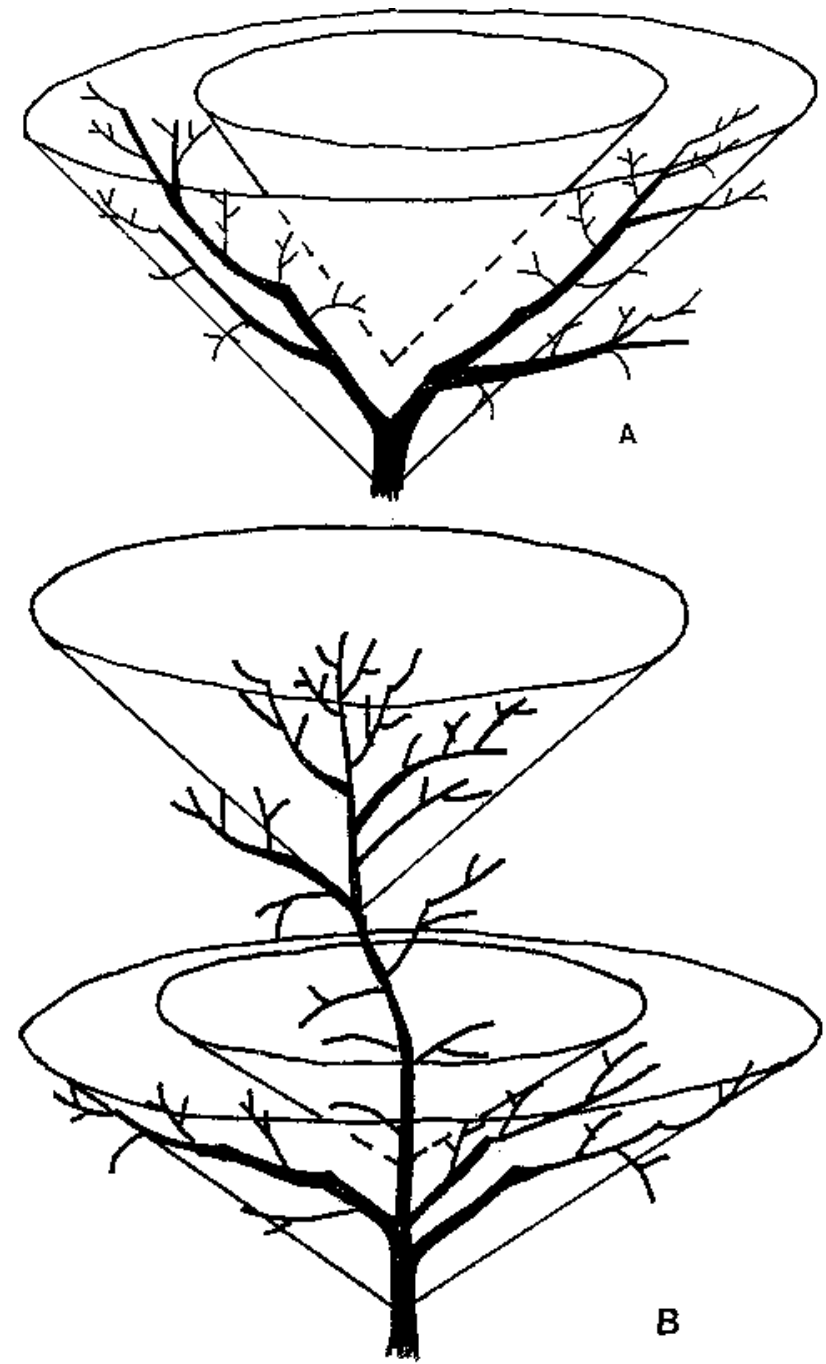

Fig. 1. Six-year-old 'Sweet Sue' peach trees trained as (A) open-vase or (B) central-leader forms. Canopy volumes were calculated by subtracting the volume of a cone devoid of fruiting shoots (interior cone) from the volume of a cone containing fruiting shoots (exterior cone). 
The open-vase form is typical for peach trees in the mid-Atlantic region (Marini, 1990). During the first three seasons, three or four wide-angled scaffold branches were selected per tree and bench cuts were used to develop a low-spreading canopy. Starting in 1987, trees were summer-pruned annually $\approx 50$ days after bloom to remove upright watersprouts and to improve light penetration into the canopy. The central-leader tree form was developed by selecting three or four wide-angled scaffold limbs per tree located at $\approx 1 \mathrm{~m}$ above ground. Five or six short ( $<50 \mathrm{~cm}$ long) 1 - and 2-yearold shoots were retained on the central leader from 1.1 to $2.0 \mathrm{~m}$ above ground. A second tier of branches, 0.75 to $1.25 \mathrm{~m}$ long, was retained at $\approx 2.3$ to $2.6 \mathrm{~m}$ above ground. The central leader was not headed and the trees were not supported. Central-leader tree height was limited to $\approx 4.2 \mathrm{~m}$ in 1990 by cutting into 2 -yearold wood to a weak side branch originating about $4 \mathrm{~m}$ above ground. Central-leader trees were summer-pruned annually $\approx 50$ days after bloom to remove upright watersprouts developing on the scaffold limbs.

Trees bloomed in 1989 and 1990, but spring frost eliminated the crops. Trees cropped in 1991 and 1992 were hand-thinned 45 days after full bloom to a spacing of $15 \mathrm{~cm}$ between fruit. During harvest, fruit were counted and weighed and mean fruit weight (FW) was calculated. Fruit were graded into four categories with a chain sizer and the number of 17.25$\mathrm{kg}$ boxes per size category per tree was recorded. Crop value was calculated using prices for Appalachian peaches during early Sept. 1992 (The Packer, 1992).

Trunk circumference, tree height, and tree spread were recorded each winter. In Nov. 1991 and 1992, the volume of canopy that contained fruiting shoots of each tree was estimated as follows. Open-vase trees were considered a cone, and total tree volume $=1 /$ $3(\mathrm{BH})$, where $\mathrm{B}=$ the area at the top of the cone and $\mathrm{H}=$ the height of the cone. Tree volume containing fruiting shoots was calculated by subtracting the volume of a smaller, hollow cone (a cone devoid of fruiting shoots at the tree interior) from the total volume of the canopy (a cone calculated from the peripheral dimensions of the canopy) (Fig. 1A). Centralleader trees were divided into bottom and top sections (Fig. 1B). The bottom and top canopy sections were considered cones and volume containing fruiting shoots was calculated for the bottom section as described for open-vase trees. The top section was considered a solid cone with fruiting shoots throughout the volume of the cone. Bottom and top volumes were summed to estimate total fruiting canopy volume.

Statistical analyses. The design was completely randomized with a $2 \times 2$ factorial arrangement of heading height and tree form. Data for yield, fruit per tree, fruit weight, crop density, yield efficiency, fruit size, and canopy volume were tested with analysis of variance using Type III sums of squares of SAS's General Linear Model(GLM) Procedure (SAS Institute, 1990).

Tree height and spread and trunk cross-
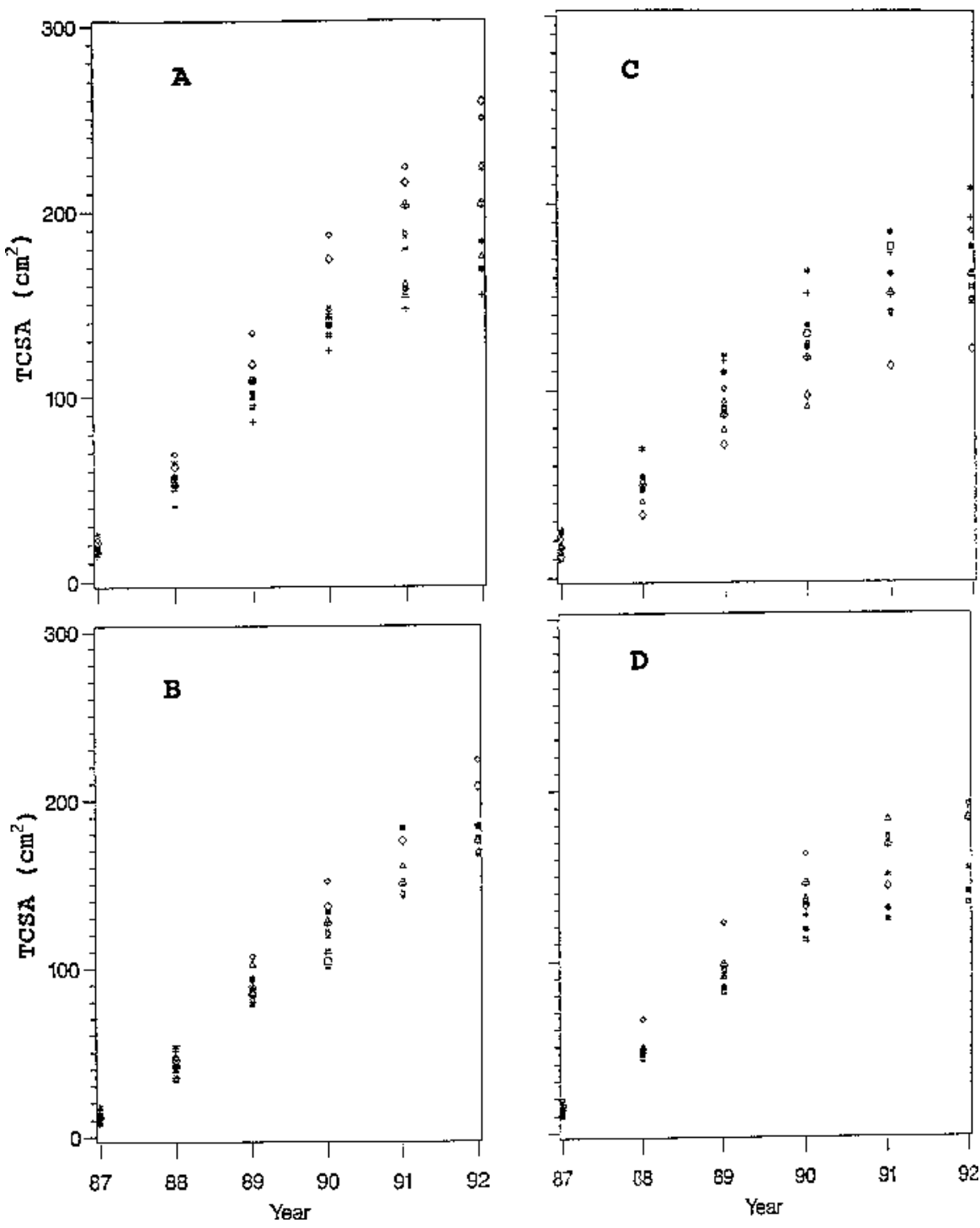

Fig. 2. Scatter plots of trunk cross-sectional area (TCSA) against year for individual 'Sweet Sue' peach trees. Treatments were (A) high-headed open vase, $(\mathbf{B})$ low-headed open vase, $(\mathbf{C})$ high-headed central leader, and (D) low-headed central leader. Symbols for individual trees include $\diamond,+, \#, \boldsymbol{\bullet}, \bullet, \square, *, \Delta, \Phi$.

Table 1. $P$ values for main effects and interactions from repeated-measures analysis of variances for tree height, tree spread, and trunk cross-sectional area (TCSA).

\begin{tabular}{llcc}
\hline & \multicolumn{3}{c}{ Response variable } \\
\cline { 2 - 4 } Source of variation & TCSA & Tree ht & Tree spread \\
\hline Heading height $(\mathrm{HH})^{\mathrm{z}}$ & 0.087 & 0.384 & 0.075 \\
Tree form $(\mathrm{TF})^{\mathrm{z}}$ & 0.121 & 0.001 & 0.001 \\
$\mathrm{HH} \times \mathrm{TF}^{\mathrm{z}}$ & 0.270 & 0.959 & 0.114 \\
Year $(\mathrm{Y})^{\mathrm{y}}$ & 0.001 & 0.001 & 0.001 \\
$\mathrm{Y} \times \mathrm{HH}^{\mathrm{y}}$ & 0.236 & 0.015 & 0.054 \\
$\mathrm{Y} \times \mathrm{TF}^{\mathrm{y}}$ & 0.110 & 0.001 & 0.001 \\
$\mathrm{Y} \times \mathrm{HH}^{\mathrm{T}} \mathrm{TF}^{\mathrm{y}}$ & 0.575 & 0.487 & 0.929 \\
\hline
\end{tabular}

${ }^{2}$ Tests the hypothesis that treatments (between-subjects effects) have no effect on the response variables, ignoring within-subject effects. This is the treatment effect when averaged over all years.

${ }^{y}$ Results from MANOVA tests of hypotheses for within-subject (measurements taken repeatedly on each tree) effects.

sectional area (TCSA) were measured annually. Measurements taken on the same tree over time are often correlated. Therefore, the H-F condition (Huynh-Feldt, 1970), which is required for univariate analysis of variance (ANOVA) $\mathrm{F}$ tests for effects involving time and interactions with time, may not hold. The $\mathrm{H}-\mathrm{F}$ condition requires that all pairs of measurements have a certain correlation structure.
The H-F condition was evaluated with the sphericity test using the PRINTE option of the REPEATED statement of SAS's GLM Procedure (Littell, 1989). Because the sphericity test was rejected for all three response variables $(P<0.001)$, these data were analyzed with a multivariate repeated-measures analysis using the REPEATED statement of SAS's GLMProcedure. Multivariate analysis requires 
no assumptions about the covariance structure of the repeated measures (Littell, 1989). Because multivariate tests tend to be conservative, the G-G adjustments for the univariate tests also were evaluated, as suggested by Littell (1989), and generally agreed with the multivariate tests. $P$ values from the multivariate ANOVA (MANOVA) are presented for the main effect of YEAR and all interactions involving YEAR. $P$ values for the main effects of heading height and tree form and their interaction were obtained from the repeatedmeasures ANOVA tests of hypotheses for between-subject effects. $P$ values also are presented for contrast variables generated with the PROFILE transformation of the SUMMARY option in the REPEATED statement of SAS's GLM Procedure.

Presenting treatment means may give a misleading impression of the way trees typically grow over time and provides no information about variation among trees in their response to treatment over time. Therefore, TCSA, tree height, and tree spread for individual trees over time, as suggested by Matthews et al. (1990), were plotted.

\section{Results and Discussion}

At planting, trees were typical of large trees sometimes produced in commercial nurseries. There were few unbroken, usable branches within $70 \mathrm{~cm}$ of the bud union. Such trees would normally be headed higher than desired to ensure retention of at least one branch. Trees handled this way usually survive, but tree structure is poor because branches originate too high above ground. During the first summer, low-headed trees produced several upright shoots from the scion and sometimes from the rootstock. In midsummer, one shoot per tree arising from the scion was retained and all other shoots were eliminated. All high-headed trees survived. Two of the 20 low-headed trees died, but the surviving trees produced an abundance of wide-angled scaffold branches within $50 \mathrm{~cm}$ of the ground from which to develop desirable scaffold branches. In general, low-headed trees had better structure (scaffold branches had wider crotch angles) than did high-headed trees.

Our experience is that smaller trees (trunk diameter $\approx 1.5 \mathrm{~cm}$ ) survive low heading. Therefore, the two low-headed trees that died were treated as missing data and were not used to calculate means in this study.

Plots of individual trees (Fig. 2) show that some trees grew faster than others; those that initially grew rapidly generally were largest in successive years. Trunks of some trees grew little from 1991 to 1992 , whereas trunks of other trees grew at a constant rate throughout most of the study (Fig. 2). Averaged over all years, heading height and tree form did not influence TCSA, and the interactions involving year were nonsignificant $(P>0.1)$ (Table 1). Averaged over all treatments, TCSA increased significantly $(P<0.001)$ each year (Table 2). The total increase in TCSA was greater for high-headed trees than for lowheaded trees from 1987 to $1988(P=0.049)$,
Table 2. $P$ values from profile analyses for tree height, tree spread, and trunk cross-sectional area (TCSA). These analyses of variance are for the transformed variables representing the differences between adjacent years.

\begin{tabular}{|c|c|c|c|c|}
\hline \multirow{2}{*}{$\begin{array}{l}\text { Successive } \\
\text { years }\end{array}$} & \multirow[b]{2}{*}{$M^{2}{ }^{y}$} & \multicolumn{3}{|c|}{ Treatments $^{2}$} \\
\hline & & Heading ht & Tree form & Interaction \\
\hline & & TCSA & & \\
\hline $1987-88$ & 0.001 & 0.049 & 0.984 & 0.081 \\
\hline 1988-89 & 0.001 & 0.916 & 0.025 & 0.784 \\
\hline 1989-90 & 0.001 & 0.423 & 0.462 & 0.731 \\
\hline 1990-91 & 0.001 & 0.384 & 0.293 & 0.770 \\
\hline 1991-92 & 0.001 & 0.433 & 0.067 & 0.851 \\
\hline & & Tree height & & \\
\hline $1987-88$ & 0.001 & 0.001 & 0.001 & 0.769 \\
\hline 1988-89 & 0.001 & 0.109 & 0.298 & 0.485 \\
\hline 1989-90 & 0.001 & 0.198 & 0.172 & 0.437 \\
\hline 1990-91 & 0.722 & 0.447 & 0.220 & 0.367 \\
\hline 1991-92 & 0.001 & 0.995 & 0.002 & 0.309 \\
\hline & & Tree spread & & \\
\hline $1987-89$ & 0.001 & 0.027 & 0.127 & 0.652 \\
\hline 1989-90 & 0.862 & 0.015 & 0.001 & 0.754 \\
\hline 1990-91 & 0.001 & 0.043 & 0.020 & 0.454 \\
\hline 1991-92 & 0.022 & 0.929 & 0.362 & 0.929 \\
\hline
\end{tabular}

${ }^{2} P$ values for the main effects and interactions on the change in the response variables between adjacent years. ${ }^{y} P$ values for the change in the response variables for adjacent years pooled over all treatments.
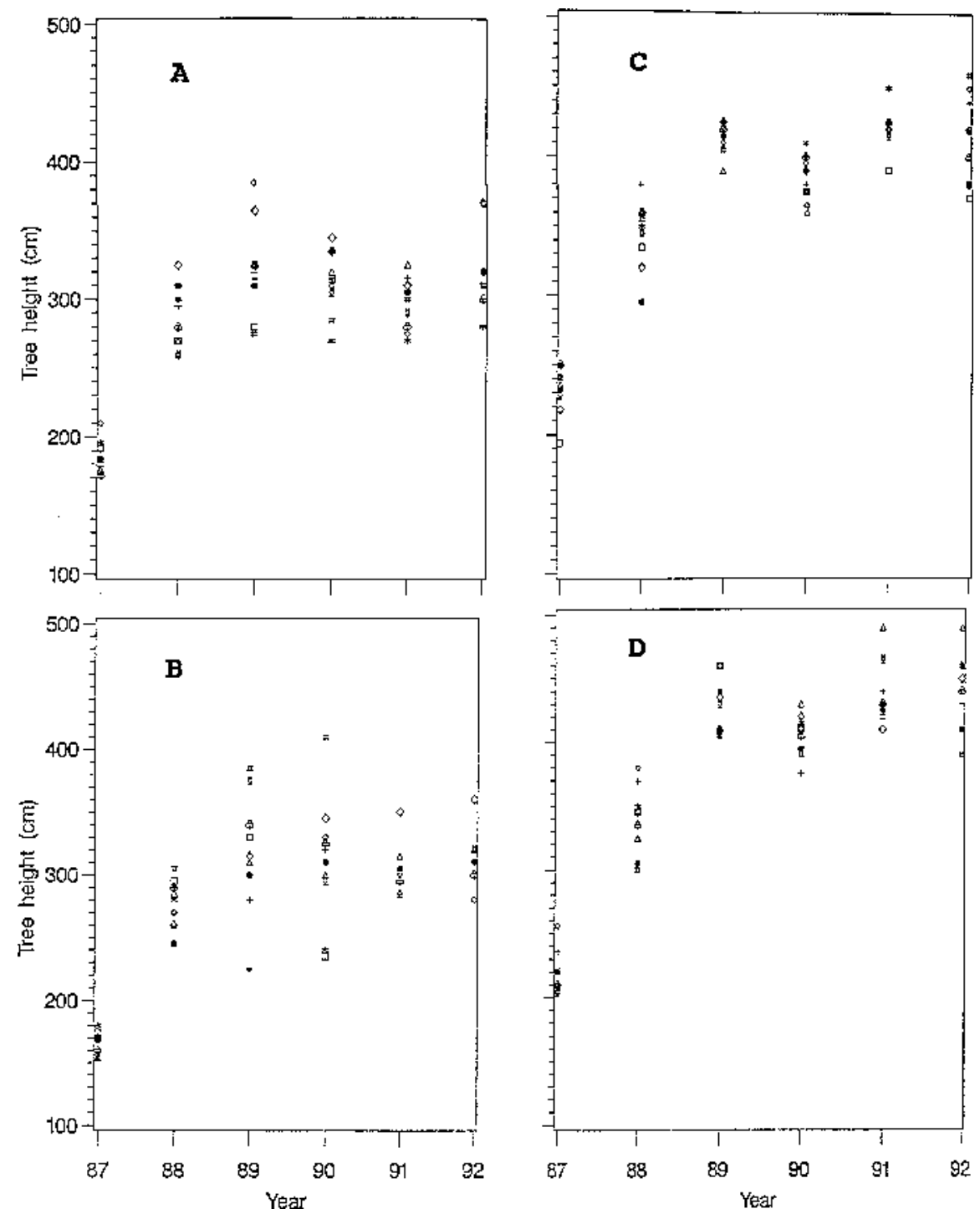

Fig. 3. Scatter plots of tree spread against year for individual 'Sweet Sue' peach trees. Treatments were (A) high-headed open vase, (B) low-headed open vase, (C) high-headed central leader, and (D) low-headed central leader. 
but heading height did not significantly influence TCSA thereafter (Table 2). The increase in TCSA was greater for open-vase trees than for central-leader trees only from 1988 to 1989 $(P=0.025)$ and from 1991 to $1992(P=0.067)$.

Tree height generally increased for most trees until 1989 when tree height was limited by dormant pruning before the 1990 season (Fig. 3). When averaged over all years, central-leader trees were taller than open-vase trees $(P=0.001)$ and there were significant year $\times$ heading height and year $\times$ tree form interactions (Table 1).

Averaged over all treatments, tree height increased significantly each year, except from 1990 to 1991 (Table 2). The increase in tree height was greater for low-headed trees than for high-headed trees from 1987 to 1988 , but heading height did not influence yearly changes in tree height thereafter (Table 2). The increase in tree height was greater for centralleader than for open-vase trees from 1987 to 1988 and greater for open-vase trees than for central-leader trees from 1991 to 1992 (Table 2).

When averaged over all treatments, tree spread increased with time $(P<0.001)$ (Table $1)$. Tree spread also was influenced by the interactions of year $\times$ heading height $(P=$ $0.054)$ and year $\times$ tree form $(P<0.001)$ Spread of open-vase trees generally increased at a decreasing rate throughout the course of the study (Fig. 4). Tree spread was not measured in 1988. Spread of central-leader trees increased until 1989, but tree spread was reduced by pruning into 2- or 3-year-old wood during Mar. 1990. Spread of central-leader trees increased $\approx 20 \mathrm{~cm} /$ year from 1990 to 1992 (Fig. 3). When averaged over all years, open-vase trees had greater spread than central-leader trees $(P<0.001)$ and high-headed trees tended to have greater spread than lowheaded trees $(P=0.075)$ (Table 1$)$.

For the periods 1987-89, 1989-90, and 1990-91, tree spread increased more on lowheaded than on high-headed trees (Table 2). Tree form did not significantly influence the change in tree spread from 1987 to 1989 or 1991 to 1992 (Table 2). From 1989 to 1990, tree spread increased for open-vase trees and was reduced by pruning for central-leader trees. From 1990 to 1991 tree spread increased significantly more $(P=0.02)$ for open-center trees than for central-leader trees (Table 2).

During the 1989 season, the terminal shoots on scaffold branches on central-leader trees grew nearly vertically and appeared to limit light penetration to the tree center. Therefore, in Mar. 1989, the scaffold branches were shortened by $\approx 25 \mathrm{~cm}$ by cutting to side branches. As a result of pruning, central-leader trees had the smallest spread from 1990 to 1991.

All trees required summer pruning to allow adequate light penetration to maintain fruiting wood at the tree interior. Although not quantified, central-leader trees were summerpruned more severely than open-vase trees. Smaller trunks on central-leader trees may be related to summer-pruning severity. In other studies, summer pruning reduced trunk enlargement in peach (Marini, 1985) and apple
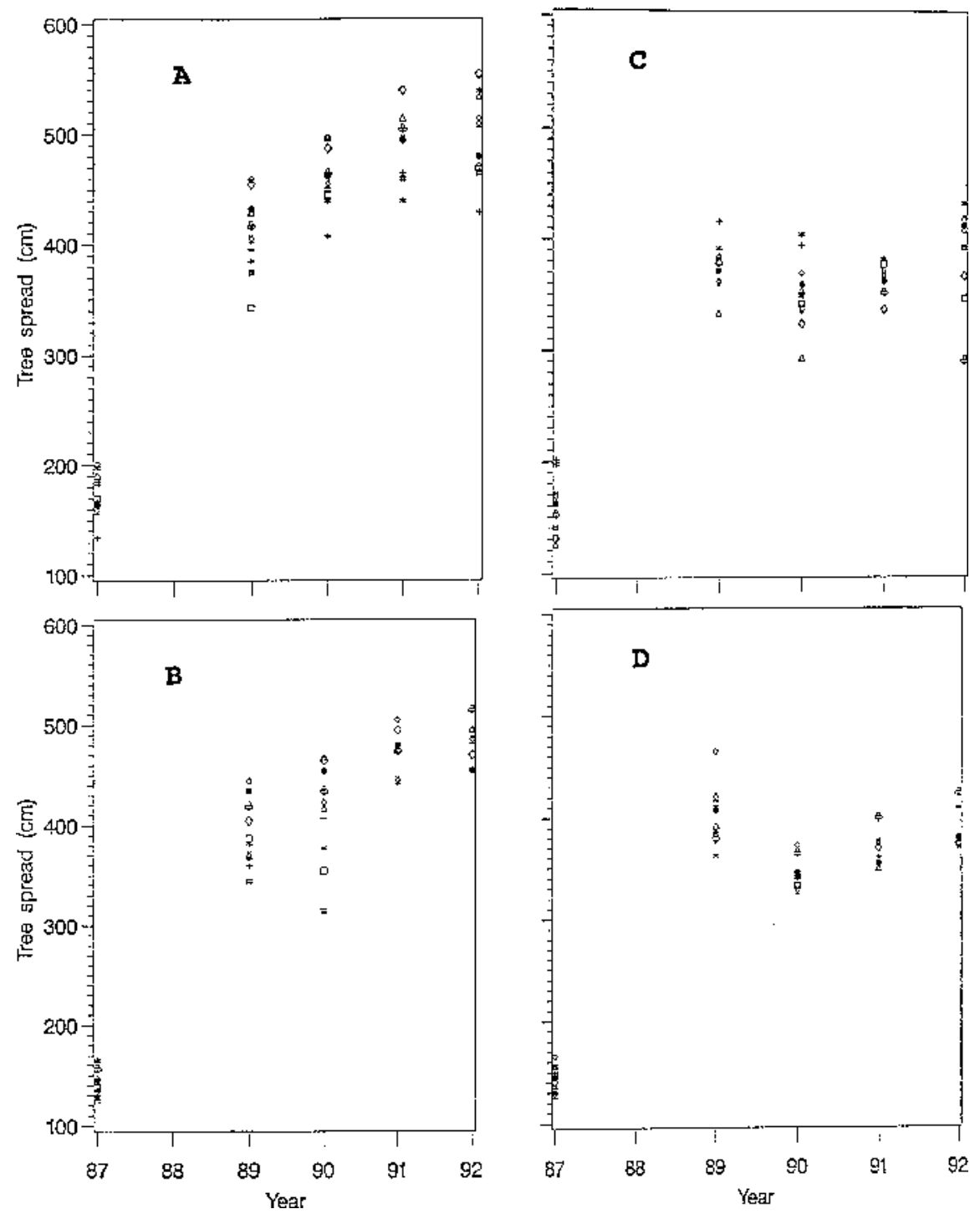

Fig. 4. Scatter plots of tree height against year for individual 'Sweet Sue' peach trees. Treatments were (A) high-headed open vase, $(\mathbf{B})$ low-headed open vase, $(\mathbf{C})$ high-headed central leader, and (D) low-headed central leader.

Table 3. Effect of heading height $(\mathrm{HH})$ at planting and tree form (TF) on yield, fruit/tree, fruit weight (FW), crop density (CD), and yield efficiency (YE) of 'Sweet Sue' peach trees planted in 1986. TFs were open vase $(\mathrm{OV})$ or central leader $(\mathrm{CL})$.

\begin{tabular}{|c|c|c|c|c|c|c|}
\hline$\underline{\mathrm{TF}}$ & $\begin{array}{l}\mathrm{HH} \\
(\mathrm{cm})\end{array}$ & $\begin{array}{c}\text { Yield } \\
(\mathrm{kg} / \text { tree })\end{array}$ & Fruit/tree & $\begin{array}{l}\text { FW } \\
(\mathrm{g})\end{array}$ & $\begin{array}{c}\mathrm{CD} \\
\left(\text { fruit } / \mathrm{cm}^{2}\right)\end{array}$ & $\begin{array}{c}\mathrm{YE} \\
\left(\mathrm{kg} \cdot \mathrm{cm}^{-2}\right)\end{array}$ \\
\hline \multicolumn{7}{|c|}{1991} \\
\hline \multirow[t]{2}{*}{ OV } & 10 & $94^{z}$ & 706 & 134 & 4.4 & 0.59 \\
\hline & 90 & 116 & 901 & 130 & 5.1 & 0.65 \\
\hline \multirow[t]{2}{*}{$\mathrm{CL}$} & 10 & 78 & 598 & 135 & 3.9 & 0.51 \\
\hline & 90 & 72 & 541 & 134 & 3.6 & 0.48 \\
\hline \multicolumn{7}{|c|}{ Significance $(P>\mathrm{F})$} \\
\hline $\mathrm{HH}$ & & 0.12 & 0.23 & 0.92 & 0.72 & 0.62 \\
\hline $\mathrm{TF}$ & & 0.01 & 0.01 & 0.17 & 0.01 & 0.01 \\
\hline $\mathrm{HH} \times \mathrm{TF}$ & & 0.02 & 0.04 & 0.70 & 0.41 & 0.40 \\
\hline \multicolumn{7}{|c|}{1992} \\
\hline \multirow[t]{2}{*}{ OV } & 10 & 103 & 678 & 152 & 3.8 & 0.57 \\
\hline & 90 & 119 & 716 & 166 & 3.5 & 0.59 \\
\hline \multirow[t]{2}{*}{ CL } & 10 & 93 & 602 & 154 & 3.7 & 0.57 \\
\hline & 90 & 94 & 605 & 155 & 3.8 & 0.59 \\
\hline \multicolumn{7}{|c|}{ Significance $(P>\mathrm{F})$} \\
\hline $\mathrm{HH}$ & & 0.06 & 0.38 & 0.01 & 0.78 & 0.26 \\
\hline $\mathrm{TF}$ & & 0.01 & 0.05 & 0.07 & 0.69 & 0.91 \\
\hline $\mathrm{HH} \times \mathrm{TF}$ & & 0.31 & 0.70 & 0.14 & 0.42 & 0.73 \\
\hline
\end{tabular}

${ }^{2}$ Values are means of eight to 10 observations. 
(Myers and Ferree, 1983) trees. Visual observations of light penetration (shaded areas and sun flecks) into the canopies indicate that central-leader tree spread should be limited to $\approx 3.5 \mathrm{~m}$. To allow adequate light penetration to the tree interior, branches longer than $\approx 1.75 \mathrm{~m}$ must be oriented $\approx 75^{\circ}$ from vertical. However, such a wide angle promotes watersprouts and the terminal ends of longer branches bend to the ground under the weight of a crop.

In general, yield and the number of fruit per tree in 1991 and 1992 were highest for highheaded, open-vase trees and lowest for central-leader trees (Table 3). In 1992, but not 1991, FW was higher for high-headed than for low-headed trees. In 1991, but not 1992, crop density (CD) and yield efficiency (YE) were higher for open-vase than for central-leader trees (Table 3).

Yield and YE in this study were greater than or equal to those reported previously for peach trees with similar TCSA in the midAtlantic region (Marini, 1985, 1986). In 1991, yield and CD for central-leader trees were only $70 \%$ and $80 \%$ that of open-vase trees, respectively, but FW was only $2 \%$ less for open-vase trees. Additionally, YE of central-leader trees was only $80 \%$ that of open-vase trees. Because YE is a measure of the amount of assimilate partitioned into fruit for trees with a given trunk size, central-leader trees apparently are no more efficient at partitioning assimilate into fruit than are open-vase trees.

In 1991, fruit size distribution was not consistently influenced by any treatment (Table 4). In 1992, high-headed, open-vase trees had the most large fruit $(\geq 65 \mathrm{~mm})$, whereas the low-headed, open-vase trees had the fewest. Because CD and YE in 1992 were similar for all treatments, we can offer no explanation for the higher fruit weight on high-headed trees.

In 1991 and 1992, the land area covered by a tree and the volume of canopy containing fruiting shoots were greater for open-vase than for central-leader trees (Table 5). In 1992 central-leader trees covered only $63 \%$ as much land and had $68 \%$ as much canopy volume as open-vase trees. However, the number and weight of fruit per unit land area was $28 \%$ and $36 \%$ greater for central-leader trees, respectively (Table 5). Number and weight of fruit per unit of canopy volume were $27 \%$ and $25 \%$ greater for central-leader trees than for openvase trees, respectively. There are few reports directly comparing peach tree form. Most researchers used higher tree densities for central-leader trees than for open-vase trees. In the fourth season, 'Newhaven' trees, planted at 1680 trees/ha and trained to an open-vase form, produced $\approx 55 \%$ more yield than centralleader trees in Illinois (Taylor, 1988). In a trial in Indiana, open-vase peach trees planted at 716 trees/ha had a cumulative yield of 23 t.ha ${ }^{-1}$, whereas central-leader trees planted at 798 trees/ha produced only $10 \mathrm{t} \cdot \mathrm{ha}^{-1}$ (Hayden and Emerson, 1988). In California, centralleader trees planted at 919 trees/ha had a cumulative yield of 64 t.ha ${ }^{-1}$, whereas open-vase trees planted at 299 trees/ha produced $55 \mathrm{t}^{\circ} \cdot \mathrm{ha}^{-1}$ (Dejong, 1988). Although, in most of these studies, tree form is confounded with tree density, central-leader trees appear less productive than open-vase trees on a per hectare basis. Data from our study do not agree with those previously reported. One possible explanation is that central-leader trees in other studies may have been planted too closely, resulting in excessive shading or pruning and low fruit production in the lower portion of the canopy (Taylor, 1988). In our study, light was likely not a limiting factor because 'Sweet Sue' trees were planted at only 308 trees/ha and were summer-pruned annually.

Table 4. Fruit size distribution of 'Sweet Sue' peaches in 1991 and 1992 as influenced by heading height $(\mathrm{HH})$ at planting and tree form $(\mathrm{TF})(\mathrm{OV}=$ open vase, $\mathrm{CL}=$ central leader $)$.

\begin{tabular}{|c|c|c|c|c|c|c|c|c|c|}
\hline \multirow[b]{3}{*}{$\mathrm{TF}$} & \multirow{3}{*}{$\begin{array}{l}\mathrm{HH} \\
(\mathrm{cm})\end{array}$} & \multicolumn{8}{|c|}{ Percentage of fruit in the following size categories $(\mathrm{mm})^{\mathrm{z}}$} \\
\hline & & \multicolumn{4}{|c|}{1991} & \multicolumn{4}{|c|}{1992} \\
\hline & & $<57$ & $57-64$ & $65-70$ & $>70$ & $<57$ & $57-64$ & $65-70$ & $>70$ \\
\hline \multirow[t]{2}{*}{$\overline{\mathrm{OV}}$} & 10 & $6^{y}$ & 26 & 45 & 23 & 32 & 42 & 24 & 1 \\
\hline & 90 & 10 & 27 & 41 & 22 & 17 & 31 & 41 & 12 \\
\hline \multirow[t]{2}{*}{ CL } & 10 & 10 & 22 & 40 & 29 & 31 & 38 & 27 & 4 \\
\hline & 90 & 9 & 20 & 45 & 26 & 27 & 43 & 28 & 2 \\
\hline \multicolumn{10}{|c|}{ Significance $(P>\mathrm{F})$} \\
\hline $\mathrm{HH}$ & & 0.99 & 0.59 & 0.28 & 0.87 & 0.03 & 0.27 & 0.03 & 0.04 \\
\hline $\mathrm{TF}$ & & 0.59 & 0.02 & 0.78 & 0.12 & 0.22 & 0.18 & 0.13 & 0.09 \\
\hline $\mathrm{HH} \times \mathrm{TF}$ & & 0.42 & 0.61 & 0.10 & 0.41 & 0.40 & 0.04 & 0.17 & 0.02 \\
\hline
\end{tabular}

${ }^{2}$ Percentage data were not transformed because treatment variances were homogeneous (Hartley's max $\mathrm{F}$ test) and residuals were normally distributed (Wilkes-Shapiro W test).

yValues are means of eight to 10 observations.

Table 5. Effect of heading height $(\mathrm{HH})$ at planting and tree form (TF) on canopy size and yield per unit land occupied by a tree and yield per unit canopy volume of 'Sweet Sue' peach trees planted in 1986 . TFs were open vase $(\mathrm{OV})$ or central leader $(\mathrm{CL})$.

\begin{tabular}{|c|c|c|c|c|c|c|c|}
\hline$\underline{\mathrm{TF}}$ & $\begin{array}{l}\mathrm{HH} \\
(\mathrm{cm})\end{array}$ & $\begin{array}{l}\text { Area under } \\
\text { the canopy } \\
\left(\mathrm{m}^{2}\right)\end{array}$ & $\begin{array}{c}\text { Fruit } / \mathrm{m}^{2} \\
\text { of land } \\
\text { area } \\
\end{array}$ & $\begin{array}{c}\mathrm{kg} \text { Fruit } / \mathrm{m}^{2} \\
\text { of land } \\
\text { area }\end{array}$ & $\begin{array}{c}\text { Canopy vol } \\
\left(\mathrm{m}^{3}\right)\end{array}$ & $\begin{array}{c}\text { Fruit } / \mathrm{m}^{3} \\
\text { canopy } \\
\text { vol }\end{array}$ & $\begin{array}{c}\mathrm{kg} \text { Fruit } / \mathrm{m}^{3} \\
\text { canopy } \\
\text { vol } \\
\end{array}$ \\
\hline \multicolumn{8}{|c|}{1991} \\
\hline \multirow[t]{2}{*}{ OV } & 10 & $16.9^{2}$ & 42.7 & 0.64 & 8.8 & 81.7 & 10.8 \\
\hline & 90 & 18.9 & 48.2 & 1.00 & 9.9 & 94.4 & 12.0 \\
\hline \multirow{2}{*}{ CL } & 10 & 10.8 & 56.6 & 1.95 & 6.7 & 91.0 & 12.0 \\
\hline & 90 & 10.4 & 52.5 & 1.36 & 6.2 & 87.8 & 11.8 \\
\hline \multicolumn{8}{|c|}{ Significance $(P>\mathrm{F})$} \\
\hline $\mathrm{HH}$ & & 0.30 & 0.92 & 0.88 & 0.65 & 0.56 & 0.42 \\
\hline $\mathrm{TF}$ & & 0.01 & 0.09 & 0.02 & 0.01 & 0.99 & 0.56 \\
\hline $\mathrm{HH} \times \mathrm{TF}$ & & 0.09 & 0.61 & 0.62 & 0.16 & 0.61 & 0.61 \\
\hline \multicolumn{8}{|c|}{1992} \\
\hline \multirow[t]{2}{*}{$\mathrm{OV}$} & 10 & 17.5 & 54.0 & 0.59 & 12.6 & 54.0 & 8.2 \\
\hline & 70 & 19.4 & 48.0 & 0.62 & 15.3 & 48.0 & 8.0 \\
\hline \multirow[t]{2}{*}{ CL } & 10 & 11.6 & 64.8 & 0.81 & 9.6 & 64.8 & 10.0 \\
\hline & 70 & 11.7 & 65.6 & 0.84 & 9.4 & 65.6 & 10.2 \\
\hline \multicolumn{8}{|c|}{ Significance $(P>\mathrm{F})$} \\
\hline $\mathrm{HH}$ & & 0.39 & 0.87 & 0.27 & 0.32 & 0.81 & 0.25 \\
\hline $\mathrm{TF}$ & & 0.01 & 0.04 & 0.01 & 0.01 & 0.01 & 0.01 \\
\hline $\mathrm{HH} \times \mathrm{TF}$ & & 0.57 & 0.56 & 0.78 & 0.36 & 0.86 & 0.70 \\
\hline
\end{tabular}

${ }^{2}$ Values are means of eight to 10 observations.

Table 6. Effect of heading height $(\mathrm{HH})$ at planting and tree form (TF) on crop value per tree, crop value per unit land area covered per tree, and crop value per unit canopy volume of 'Sweet Sue' peach trees planted in 1986. TFs were open vase (OV) or central leader (CL).

\begin{tabular}{|c|c|c|c|c|c|c|c|}
\hline \multirow[b]{2}{*}{ TF } & \multirow{2}{*}{$\begin{array}{l}\mathrm{HH} \\
(\mathrm{cm})\end{array}$} & \multicolumn{2}{|c|}{$\begin{array}{c}\text { Crop value } \\
\text { (\$/tree) }\end{array}$} & \multicolumn{2}{|c|}{$\begin{array}{c}\$ / \mathrm{m}^{2} \\
\text { land area }\end{array}$} & \multicolumn{2}{|c|}{$\begin{array}{c}\$ / \mathrm{m}^{3} \\
\text { canopy vol }\end{array}$} \\
\hline & & 1991 & 1992 & $\overline{1991}$ & 1992 & 1991 & 1992 \\
\hline \multirow[t]{2}{*}{$\overline{\mathrm{OV}}$} & 10 & 44.81 & 50.04 & 2.68 & 2.86 & 5.14 & 3.95 \\
\hline & 90 & 53.51 & 59.91 & 2.85 & 3.13 & 5.54 & 4.03 \\
\hline \multirow[t]{2}{*}{ CL } & 10 & 36.52 & 45.27 & 3.43 & 3.96 & 5.62 & 4.87 \\
\hline & 90 & 34.34 & 46.23 & 3.34 & 4.12 & 5.60 & 5.00 \\
\hline \multicolumn{8}{|c|}{ Significance $(P>\mathrm{F})$} \\
\hline $\mathrm{HH}$ & & 0.10 & 0.02 & 0.71 & 0.17 & 0.34 & 0.13 \\
\hline TF & & 0.01 & 0.01 & 0.01 & 0.01 & 0.31 & 0.01 \\
\hline $\mathrm{HH} \times \mathrm{TF}$ & & 0.03 & 0.21 & 0.71 & 0.72 & 0.69 & 0.60 \\
\hline
\end{tabular}

${ }^{2}$ Crop value based on prices for Appalachian peaches during early Sept. 1992, where 51-57 mm $=\$ 4.50$, $57-64 \mathrm{~mm}=\$ 7.00$, and $>64 \mathrm{~mm}=\$ 9.00 /$ box, respectively (The Packer, 1992). 
leader trees to maximize efficient use of orchard area. At such tree densities, theoretical cumulative crop values would be about $\$ 23,000 /$ ha for open-vase trees and $\$ 27,700$ / ha for central-leader trees. To verify these theoretical values further, research is needed to compare the two tree forms at various tree spacings. Additionally, costs associated with pruning, fruit thinning, and harvesting the two tree forms must be recorded. Our data indicate that at appropriate tree densities, the centralleader tree form may be at least equally profitable as the traditional open-vase form currently used by mid-Atlantic peach producers.

\section{Literature Cited}

Campbell, R.J. and R.P. Marini. 1992. Light environment and time of harvest affect 'Delicious' apple fruit quality characteristics. J. Amer. Soc. Hort. Sci. 117:551-557.

DeJong, T.M. 1988. Peach planting/training systems in California, p. 418-423. In: N.F. Childers and W.B. Sherman (eds.). The peach. Hort Publications, Gainesville, Fla.

Forshey, C.G. and M.W. McKee. 1970. Production efficiency of a large and a small 'McIntosh' apple tree. HortScience 5:164-165.

Hayden, R.A. and F.H. Emerson. 1988. High density plantings for peaches, p. 404-411. In: N.F
Childers and W.B. Sherman (eds.). The peach. Hort. Publications, Gainesville, Fla.

Huynh, H. and L.S. Feldt. 1970. Conditions under which mean square ratios in repeated measurements design have exact F-distributions. J. Amer. Stat. Assn. 65:1582-1589.

Jackson, J.E. 1978. Utilization of light resources by high density planting systems. Acta Hort. 65:6170.

Jackson, J.E. 1980. Light interception and utilization by orchard systems. Hort. Rev. 2:208-267.

Littell, R.C. 1989. Statistical analysis of experiments with repeated measures. HortScience 24:37-40.

Marini, R.P. 1985. Sample size estimates for peach tree growth and yield experiments. J. Amer. Soc. Hort. Sci. 110:604-608.

Marini, R.P. 1986. Growth and cropping of 'Redhaven' peach trees following foliar applications of flurprimidol and paclobutrazol. J. Amer. Soc. Hort. Sci. 111:849-853.

Marini, R.P. 1990. Pruning peach trees. Virginia Coop. Ext. Bul. \#422-020.

Marini, R.P. and M.C. Marini. 1983. Seasonal changes in specific leaf weight, net photosynthesis, and chlorophyll content of peach leaves as affected by light penetration and canopy position. J. Amer. Soc. Hort. Sci. 108:600-605.

Marini, R.P., D. Sowers, and M.C. Marini. 1991. Peach fruit quality is affected by shade during final swell of fruit growth. J. Amer. Soc. Hort. Sci. 116:383-389.
Matthews, J.N.S., D.G. Altman, M.J. Campbell, and P. Royston. 1990. Analysis of serial measurements in medical research. Brit. Medical J. 300:230-235.

Menzies, A.R. 1988. Evolution of peach tree forms in New South Wales, Australia, p. 446-465. In N.F. Childers and W.B. Sherman (eds.). The peach. Hort. Publications, Gainesville, Fla.

Miller, A. and C. Walsh. 1988. Growth and seasonal partitioning of dry matter in 8-year-old 'Loring' peach trees. J. Amer. Soc. Hort. Sci. 113:309314.

Myers, S.C. and D.C. Ferree. 1983. Influence of time of summer pruning and limb orientation on yield, fruit size, and quality of vigorous 'Delicious' apple trees. J. Amer. Soc. Hort. Sci. 108:630-633.

Patten, K.D. and E.L. Proebsting. 1986. Effect of different artificial shading time and natural light intensities on fruit quality of 'Bing' sweet cherry. J. Amer. Soc. Hort. Sci. 111:360-363.

SAS Institute. 1990. SAS/STAT user's guide, version 6, 4th ed. SAS Inst., Cary, N.C.

Southwick, S.M., S.A. Weinbaum, T.T. Muraoka, W.R. Krueger, K.A. Schackel, and J.T. Yeager. 1990. Leaf attributes as indices of fruit quality in prune tree canopies. HortScience 25:751754.

Taylor, B.H. 1988. Promising high density peach production systems in Illinois, p. 491-498. In: N.F. Childers and W.B. Sherman (eds.). The peach. Hort. Publications, Gainesville, Fla. 